\title{
Identification of proanthocyanidins extracted from Pinus radiata D. Don bark
}

\author{
Soledad Cortés, Hugo Pulgar, Verónica Sanhueza, Estrella Aspé, and \\ Katherina Fernández \\ Facultad de Ingeniería, Departamento de Ingeniería Química, Universidad de Concepción. Casilla 160 C, \\ Correo 3, Concepción, Chile.
}

\begin{abstract}
S. Cortés, H. Pulgar, V. Sanhueza, E. Aspé, and K. Fernández. 2010. Identification of proanthocyanidins extracted from Pinus radiata D. Don bark. Cien. Inv. Agr. 37(2): 15-25. The bark of Pinus radiata D. Don is recognized as a rich natural source of proanthocyanidins (PAs). Barks of Pinus radiata D. Don were extracted to produce a raw extract, and then purified to produce 4 fractions, with the aim of correlating its structural characteristics with the extract antioxidant capacity. The structural characterization was performed by acid catalysis in presence of phloroglucinol, followed by the detection of the components by High Precision Liquid Chromatography (HPLC). The subunits identified in the bark of Pinus radiata were: epicatechin- (4ß-2) - phloroglucinol (EC-P), catechin- $(4 \alpha-2)$ - phloroglucinol (C-F) and $(+)$ catechin $(\mathrm{C})$. The purified fractions showed different mean degree of polymerization $(\mathrm{mDP})$, average molecular weight (aMW), concentration and reaction yield (R) with phloroglucinol. The concentration of total phenols decreased according to the order in which the fractions were eluted. All the fractions presented a high antiradical activity (evaluated as scavenging capacity of radical DPPH•). Nevertheless, the fraction FII presented the greatest tannin concentration and antioxidant activity. The structural characteristics of the extract of Pinus radiata D. Don bark could be correlated with the antioxidant activity of the extract.
\end{abstract}

Key words: Antioxidant activity, bark, Pinus radiata, tannins.

\section{Introduction}

The main economic activity of the Chilean forest industry corresponds to cellulose, and secondly, the sawn wood industry. In both activities, the most used tree species is Pinus radiata D. Don (CORMA, 2007). However, tree bark is not completely used in those activities, and its

Received July 12, 2009. Accepted October 07, 2009. Corresponding author: kfernandeze@udec.cl removal is one of the first industrial operations before processing the trunk (Egaña y Palma, 1999). This fact has caused that bark generates an important volume of residues produced in the forest industry, represented by 10 to $15 \%$ of the total weight of the tree (Rosales and González, 2003). Regardless the reported presence of components with different bioactivities in bark (Balaban and Ucar, 2001; Ku and Mun, 2008), whose chemical characteristics open the possibility of elaborating products of natural origin with new uses and activities and with higher added value, this abundant resource is still used for board and panel fabrication and underused as fuel. 
Bark, like wood, is chemically formed mainly by: cellulose, lignin and extractable substances, formed from the secondary metabolism of plants which contain varied compounds like terpens, fats, waxes, phenoles and sugars, among others (Rosales and Gonzáles, 2003). The same authors mention that its chemical composition depends on diverse factors like age, species, conditions and localization of the tree. Phenols are an important group of these compounds because of their abundance, diversity and complexity. Proanthocyanidins (PAs) or bark condensed tannins outstand in this group, due to their acknowledged antioxidant (Jerez et al., 2006; Koleckar et al., 2008; Scalbert et al., 2005), antifungal (Mihara et al., 2005), anticarcinogenic (Cutler et al., 2008), antihypertensive (Nishioka et al., 2007) properties; in addition, they have a high inhibitory activity against several carbohydrates hydrolyzing enzymes, which might indicate their potential as a antihyperglicemic drug (Kim et al., 2004).

Proanthocyanidins (PAs) or condensed tannins, are oligomer and polymers from flavan3-ols, whose composition and structure depend on the vegetal source where they are extracted (they are secondary metabolites found in all vascular plants). The chemical structure of the monomers is characterized by flavan-3-ol as an essential unit, which is called (+)- catechin (C), (-)-epicatechin (EC), (-)-epicatechin-3$O$-gallate (ECG), (-)-epigalocatechin (EGC) and $(-)$-epigalocatechin-3-O-gallate (ECGG), depending on the substitution of the $\mathrm{B}$ ring. In plants, these basic chemical components may be found forming dimers, trimers, tetramers and in higher combinations, forming polymers. When more than 5 units are quantified in a molecule, it is called PA; those compounds are formed by flavan-3-ols subunits joined mainly by links $\mathrm{C}_{4} \rightarrow \mathrm{C}_{8}$ o $\mathrm{C}_{4} \rightarrow \mathrm{C}_{6}$ (Schofield et al., 2001; Hagerman, 2002).

It has been determined that the antioxidant capacity of PAs depends to a great extent on their structure and particularly, on the mean degree of polymerization (mDP) (Jerez et al., 2007a;
Ku y Mun, 2007; Tourio et al., 2005). Those authors have reported different $\mathrm{mDP}$ degrees, depending on pine species, with maximum values of 14.6 (Jerez et al., 2007a) and 13 (Ku and Mun, 2007) for Pinus radiata; 22.2 (Jerez et al., 2007a) and 3.4 (Tourino et al., 2005) for Pinus pinaster. Nevertheless, obtaining a higher antioxidant capacity was not coincident with the maximum $\mathrm{mDP}$ value, which suggests influence from the chemical structure on the interaction between an inhibitor and a substrate.

There are some studies in the literature reviewed about Pinus radiata cultivated in South America (Diouf et al., 2006, Palma et al., 2003); however, none of them has focused on the relation between the structural characteristics of the extract and its antioxidant properties. Therefore, the main objective of the study was to extract, purify and characterize a phenolic extract rich in proanthocyanidins from Pinus radiata bark, from the Bío Bío Region (Chile) and relate the antioxidant power of the extracts to their mDP.

\section{Materials and methods}

Bark from Pinus radiata D. Don was obtained from the Coronel sawmill, located in Parque Industrial (Bío Bío Region, Chile), collected on August 29, 2008 and processed on September 01,2008 . The bark was obtained from trees between 15 and 20 years old. They were ground and sieved to 1 and $2 \mathrm{~mm}$ diameter particles.

Pais variety grapes (Vitis vinifera $\mathrm{L}$.) were used as standard material for structural characterization, which was harvested in the city of Quillón (Bío Bío Region, Chile), in March 2008; the fruit was frozen with liquid nitrogen and preserved at $0{ }^{\circ} \mathrm{C}$ until the standards were prepared in August 2008.

The experimental procedure was divided in 3 stages for the extraction, purification and identification of bark PAs (Figure 1). For the structural identification, the bark extract was analyzed 
by acid catalysis in presence of phoroglucinol, followed by the detection of the components in HPLC. The use of phoroglucinol as a nucleophilic agent was implemented by Kennedy and Jones (2001) to research the PAs composition extracted from seeds and skin of grapes. In the present article, such methodology was adapted to characterize PAs from Pinus radiata D. Don bark by HPLC, using pure standards of catechin and epicatechin, from grape seeds and skin. These last samples were used due to the presence of the flavonoid subunits in seeds, and skins; which has been previously identified (Kennedy and Jones, 2001). Therefore, one or more of these subunits usually present in grapes may be found in pine bark.

\section{Standards preparation}

The skins and seeds were separated manually and extracted separately in Erlenmeyer flasks with $250 \mathrm{~mL}$ of acetone/water $(2: 1 \% \mathrm{v} / \mathrm{v})$, during 24 hours in a G24 orbital shaker (100 rpm, New Brunswick Scientific Co. Inc., NJ, USA). The resulting extracts were filtered and vacuum concentrated in a rotary evaporator $\left(\mathrm{T}<35^{\circ} \mathrm{C}\right)$ and then lyophilized. Unlike the skin, the resulting raw seeds extract was washed 3 times with $50 \mathrm{~mL}$ of hexane in decantation funnels before lyophilization to eliminate oils (Kennedy and Jones, 2001).

The raw skin and seed extracts were purified by cromatographic exclusion (Toyopearl HW40 F, $500 \mathrm{~mL}$ ) (Kennedy and Taylor, 2003). The Omnifit chromatographic column $(3,5 \mathrm{x} 49 \mathrm{~cm})$ was balanced with two column volumes of a 1:1 $\mathrm{MeOH} /$ water mixture $(0,1 \% \mathrm{v} / \mathrm{v}$ trifluoroacetic acid, TFA). The raw extract ( $2 \mathrm{~g})$ was dissolved in $25 \mathrm{~mL}$ of this mobile phase, and was injected to the column, and then washed with 5 column volumes of the same mobile phase to eliminate the carbohydrates and the material of low molecular weight. The material retained was eluted with 3 column volumes of acetone/water (2:1) $(0.1 \% \mathrm{v} / \mathrm{v}$ TFA $)$ to a flow of $7 \mathrm{~mL} \cdot \mathrm{min}^{-1}$. Then, the sample was concentrated and lyophilized, to be further used as standards in the PAs characterization of bark, when the respective ellusion times of each component were compared.

\section{Extraction of bark PAs}

Bark (20 g) from Pinus radiata D. Don of homogeneous size (1-2 $\mathrm{mm}$ ) was extracted with

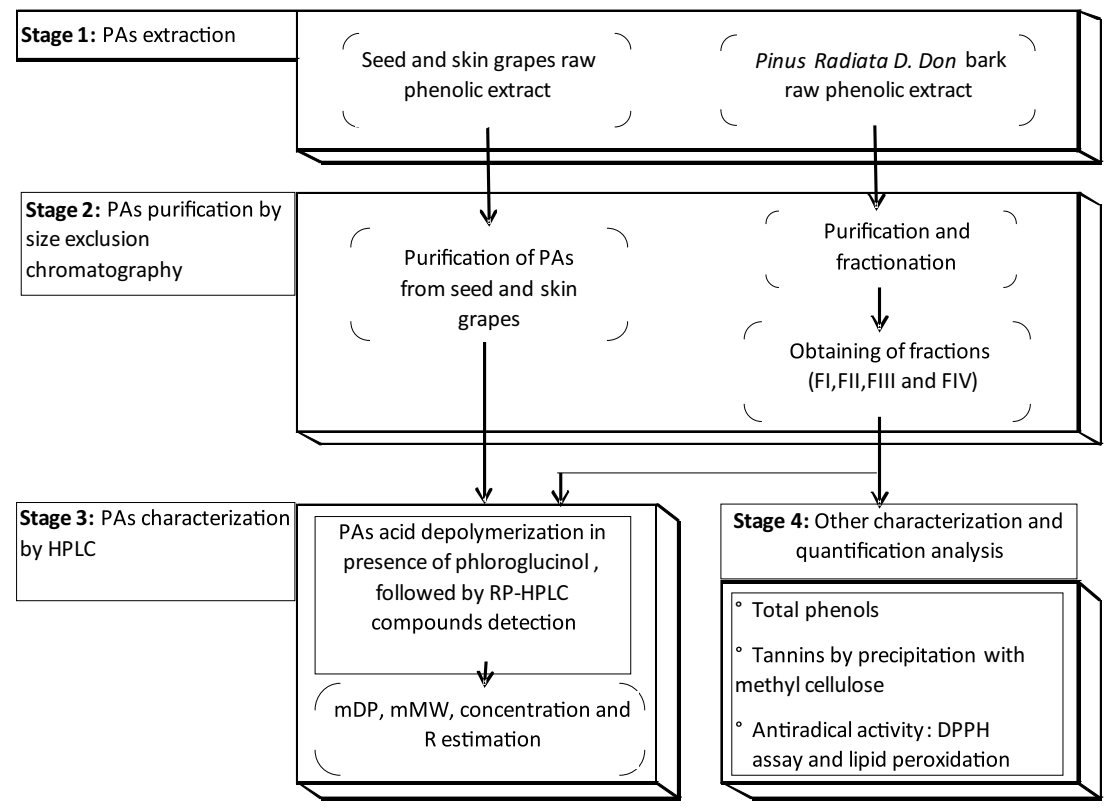

Figure 1. Flow diagram of the experimental procedure. 
$200 \mathrm{~mL}$ of acetone/water $(7: 3 \% \mathrm{v} / \mathrm{v})$, for one hour with continous shake $(120 \mathrm{rpm})$ at room temperature. The resulting extract was filtered and concentrated at reduced pressure $\left(\mathrm{T}<35^{\circ} \mathrm{C}\right)$ to eliminate the acetone, washed with hexane 3 times $(50 \mathrm{~mL})$ to eliminate the resin and then lyophilized and preserved at $4{ }^{\circ} \mathrm{C}$ for future analysis. This extract was called unpurified proanthocyanidins (PASP).

\section{Purification and fractioning of bark extracts}

The fractioning of bark PAs was made in order to produce fractions with different structural characteristics. Thus, the elution was used in a gradient proposed by Jerez et al. (2007a) with modifications, each mixture of solvents used was increased in $100 \mathrm{~mL}$ and the type of resin used was changed.

The column packed with Toyopearl HW-40F $(500 \mathrm{~mL})$ was balanced with a methanol/water/TFA mixture (3:2:0.1\% v/v/v) (two column volumes). The raw phenolic bark extract $(3 \mathrm{~g})$ was dissolved in $50 \mathrm{~mL}$ of this mobile phase and then injected to the column. The fractions were eluted with the sequence of solvents mixture shown in Table 1 with a flow of $7 \mathrm{~mL} \cdot \mathrm{min}^{-1}$. The fractions FI, FII, FIII and FIV were collected in the specified intervals, according to the chromatographic profile obtained (Figure 2 ), considering the time zero the moment when the PAs are injected in the mobile phase. The fraction F0 was eliminated from the analysis, as it corresponds to phenolic compounds of low molecular weight, sugars and acids according to the indications by Kennedy and Jones (2001). The rest of the fractions were concentrated at reduced pressure and lyophilized for a further characterization.

\section{Identification of Bark PAs}

Acid catalysis in presence of phoroglucinol. Once the PAs have been purified by size exclusion chromatography, the conversion of PAs in their constitutive subunits (resulting adducts and free flavan-3-ols) was made by the acid de- polymerization in presence of excess of phoroglucinol (Kennedy and Jones, 2001; Kennedy and Taylor, 2003). A $0.1 \mathrm{~N}$ solution of $\mathrm{HCl}$ in ethanol was prepared, containing $50 \mathrm{~g} \cdot \mathrm{L}^{-1}$ phoroglucinol and $10 \mathrm{~g} \cdot \mathrm{L}^{-1}$ of ascorbic acid. The PAs reacted in this solution $\left(10 \mathrm{~g} \cdot \mathrm{L}^{-1}\right)$ at $50{ }^{\circ} \mathrm{C}$ during 20 minutes, and then they were combined with 5 volumes of aqueous sodium acetate of 40 $\mathrm{mM}$ to stop the reaction. The resulting products (monomers flavan-3-ols and phoroglucinol adducts) were analyzed by HPLC (HitachiMerk LaChrom L7000 series, Japan). Thus, a binary gradient containing a mobile phase A $(1 \% \mathrm{v} / \mathrm{v}$ of aqueous acetic acid) and a mobile phase B ( $1 \% \mathrm{v} / \mathrm{v}$ of acetic acid /acetonitrile) were used. The elution peaks were detected at $280 \mathrm{~nm}$. It is noteworthy the importance that the structural PAs depolymerization, by the action of a nucleophílic agent (phoroglucinol, mercaptan, thiol), occurs before using HPLC, for the detection of components. This is important because if that depolymerization is not performed, the HPLC chromatogram would show a wider peak which would indicate the presence of a proanthocyanidins mixture, hindering the detection of individual components (Jerez et al., 2007a).

Table 1. Solvents used in the purification of bark extract.

\begin{tabular}{lccc}
\hline $\begin{array}{l}\text { Solvent } \\
\text { Volume (mL) }\end{array}$ & $\begin{array}{c}\text { Acetone } \\
(\% \text { vol. })\end{array}$ & $\begin{array}{r}\text { Methanol } \\
(\% \text { vol. })\end{array}$ & $\begin{array}{c}\text { Water } \\
(\% \text { vol. })\end{array}$ \\
\hline 640 & 0 & 60 & 40 \\
340 & 0 & 75 & 25 \\
490 & 0 & 90 & 10 \\
460 & 10 & 80 & 10 \\
400 & 20 & 65 & 15 \\
700 & 30 & 40 & 30 \\
800 & 70 & 0 & 30 \\
\hline
\end{tabular}

The parameters calculated were: mean Degree of Polymerization (mDP), mean Molecular Weight (mMW), concentration and yield (R) in regard to the initial mass of PAs that had a reaction. $R$ was evaluated as the sum of the mass of all the subunits divided by the initial PAs mass used in 
the reaction. These parameters were calculated using a catechin standard as reference. The PAs concentration was expressed as equivalent miligrams of catechin per gram of extract $(\mathrm{mg} \mathrm{C} \cdot \mathrm{g}$ extract $\left.^{-1}\right)$.

Total phenols. $2.5 \mathrm{ml}$ of commercial reactive (Folin-Ciocalteu) diluted 10 times were mixed with $2 \mathrm{~mL}$ of sodium carbonate at $7.5 \%$ and 0.5 $\mathrm{mL}$ of phenolic extract $\left(0.1 \mathrm{~g} \cdot \mathrm{L}^{-1}\right)$. After heating for 15 minutes at $45^{\circ} \mathrm{C}$, the absorbance was measured at $765 \mathrm{~nm}$ in a UV-VIS spectrophotometer (Shimadzu UV-1203, Japan). A blank was made using the reactives in the same proportion described, but replacing the $0.5 \mathrm{~mL}$ of extract for deionized water (Jerez et al., 2006). A catechin curve in solution was used as standard of reference. The concentration of total phenols $\left(C_{f}\right)$ was expressed as equivalent grams of catechin per gram of extract ( $\mathrm{g}$ eq.C.g extract ${ }^{-1}$ ).

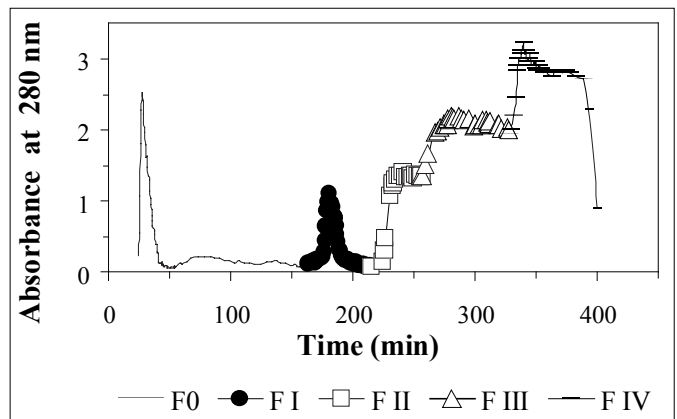

Figure 2. Chromatographic profile from the purification of the bark phenolic extract of Pinus radiata D. Don in a chromatographic column packed with Toyopearl HW-40 F.

Tannins by precipitation with methylcellulose. The experimental protocol developed by Sarneckis et al. (2005) was used in order to determine the concentration of tannins and adapted by Maldonado (2008) for pine bark extracts. 1 $\mathrm{mL}$ of tannin $\left(1 \mathrm{~g} \cdot \mathrm{L}^{-1}\right)$ was mixed with $3 \mathrm{~mL}$ of metylcellulose $(0.04 \% \mathrm{p} / \mathrm{p})$, it was shaken and 3 $\mathrm{mL}$ of saturated $\left(\mathrm{NH}_{4}\right)_{2} \mathrm{SO}_{4}$ solution were added. The solution was taken to $10 \mathrm{~mL}$ with deionized water and was left to stand for 15 minutes at room temperature, and then it was centrifuged for 5 minutes at 2,218 $\mathrm{g}$. The control used was prepared mixing $1 \mathrm{~mL}$ of tannin $\left(1 \mathrm{~g} \cdot \mathrm{L}^{-1}\right)$ with $3 \mathrm{~mL}$ of saturated solution of $\left(\mathrm{NH}_{4}\right)_{2} \mathrm{SO}_{4}$ and it was taken to $10 \mathrm{~mL}$ with deionized water. The absorbance at $280 \mathrm{~nm}$ was determined for both the sample and the control (Shimadzu UV-1203, Japan). The blank used was deionized water. A catechin curve in solution was used as a standard of reference. The concentration of tannins $\left(\mathrm{C}_{t}\right.$ ) was expressed as equivalent miligrams of catechin per gram of extract (mg eq.C $\cdot g$ extract $^{-1}$ ).

Antioxidant activity. In terms of antioxidant activity the samples of bark PAs were analyzed by two methods, DPPH (2.2-diphenyl-1-picrylhydrazyl) and lipid peroxidation, which allow, in the first case, to evaluate the PAs capacity to scavenging free radicals of $\mathrm{DPPH} \bullet$ formed, and in the second case, the phenolic extract hinders the action of free radicals on a substrate.

\section{DPPH method}

A solution of $40 \mathrm{mg} \cdot \mathrm{L}^{-1}$ of the radical DPPH dissolved in methanol was prepared. Then, 2 $\mathrm{mL}$ of this solution reacted with $1 \mathrm{~mL}$ of bark extract ( 6 and $12 \mu \mathrm{g} \cdot \mathrm{mL}^{-1}$ ) dissolved in methanol. The control consisted on mixing $1 \mathrm{~mL}$ of extract with $2 \mathrm{~mL}$ of methanol. The absorbance measured was made at $517 \mathrm{~nm}$ each 5 minutes until 30 minutes were completed. The blank was a mixture of $1 \mathrm{~mL}$ methanol with 2 $\mathrm{mL}$ of DPPH solution (Yassa et al., 2008). It needs to be taken into account that a very low value of absorbance of the reactant mixture indicates a high sequestrant capacity of free radicals (CSRL), expressed numerically as:

$\operatorname{CSRL}(\%)=100-\left[\left(\mathrm{Abs}_{\text {sample }}-\mathrm{Abs}_{\text {control }}\right) / \mathrm{Abs}_{\text {blank }}\right] \cdot 100$

The sequestrant capacity of free radicals of the bark extracts produced in these studies were compared with a commercial antioxidant, butylhydroxitoluen (BHT), using the same concentrations (6 and $\left.12 \mu \mathrm{g} \cdot \mathrm{mL}^{-1}\right)$.

\section{Lipid peroxidation}

The lipid peroxidation was made according to the methodology described by Yassa et al. (2008). A solution of $2.51 \%$ of linoleic acid $(60 \%)$ diluted 
in absolute ethanol $(0.5 \mathrm{~mL})$ reacted with $1 \mathrm{~mL}$ of the phenolic extract $\left(1 \mu \mathrm{g} \cdot \mathrm{mL}^{-1}\right)$ dissolved in methanol and $1 \mathrm{~mL}$ of a $50 \mathrm{mM}$ solution of phosphate buffer ( $\mathrm{pH}$ 7.0). The mixture was homogenized and incubated at $40{ }^{\circ} \mathrm{C}$ in darkness until the day of maximum absorbance of the control (after 192 hours of incubation). The control was prepared in the same proportion of reactives previously described, but $1 \mathrm{~mL}$ of methanol was added instead of $1 \mathrm{~mL}$ of extract, and it was incubated at $40{ }^{\circ} \mathrm{C}$ in darkness.

The test of ferric thiocyanate (FTC) was used to measure the amount of peroxide produced in the lipid peroxidation. The lipids/sample solutions $(100 \mu \mathrm{L})$ were mixed with $4.7 \mathrm{~mL}$ of ethanol $(75 \%)$ and $50 \mu \mathrm{L}$ of ammonium thiocyanate $(30 \%)$. The mixture was left to stand for 3 minutes at room temperature, $100 \mu \mathrm{L}$ of iron sulphate $(20 \mathrm{mM})$ dissolved in hydrochloric acid $(3.5 \%)$ was added to induce the formation of red ferric thiocyanate (FTC). Three minutes later the absorbance was measured at $500 \mathrm{~nm}$ to obtain a stable and maximum absorbance of the control. The blank used was methanol.

The antioxidant activity was expressed as Inhibition Percentage (IP) of the peroxidation of the linoleic acid (Yassa et al., 2008).

\section{Statistical analysis}

The analyses were made in triplicate and the results were expressed as mean values \pm Standard Deviation (SD). The average was considered to analyze the significance of results obtained ( $p$ $\leq 0.05$ ), which was analyzed statistically by the ANOVA Test and using the Least Significant Difference (LSD) procedure of Fisher.

\section{Results and discussion}

The starting point of this study was the production of a phenolic extract rich in PAs from Pinus radiata D. Don bark, which was then purified originating 4 fractions, therefore its structural characteristics are related to the antioxidant activity.

\section{Comparison of standards of purified grapes and the phenolic bark extract}

The samples of grape skin and seeds were analyzed and the elution order of the components detected (monomers flavan-3-ols and phoroglucinol adducts) was coincident with the results published by Kennedy and Jones (2001) (Figure 3 ). The presence of flavan-3-ols was detected in the pine bark samples based on grapes samples and in the direct comparison with the retention times of pure catechin and epicatechin standards (8.67 min and $10.53 \mathrm{~min}$, respectively).

It may be observed in the chromatograms of Figure 3 that not all the components identified in the seed and skin standards are present in the PASP bark sample of Pinus radiata D. Don. Therefore, based on the chromatograms comparison, retention times and pure standards, it was possible to identify 3 subunits present in the PASP bark sample: epicatechin-(4 $\beta-2)$-phoroglucinol (EC-F), catechin-( $4 \alpha-2)$-phoroglucinol (C-F) and $(+)$-catechin $(\mathrm{C})$.

At the beginning it was proposed that the higher from the two unidentified peaks, was (-)-epicatechin-3-O-gallate (ECG), as the retention time obtained for this peak (13.03 $\mathrm{min}$ ) was similar to the retention time of the ECG component present in grapes seeds (13.66 min). However, the difference existing between the retention times mentioned above was noticeably higher than the result found after the rest of the components were identified. Thus, it was impossible to assure the presence of ECG in the sample of bark PASP. Jerez et al. (2007b) reported that PAs of pine bark lack of gallate esters; on the other hand, Weber $e t$ al. (2007) indicated the presence of gallate esters in extracts of pine bark. Due to the uncertainty existing in the results found in the bibliography, this study did not consider the peak that might correspond to ECG. It might be determined in future works whether the bark PAs (obtained in this study) contains gallate esters, by mass spectometry or HPLC using pure ECG standards. 

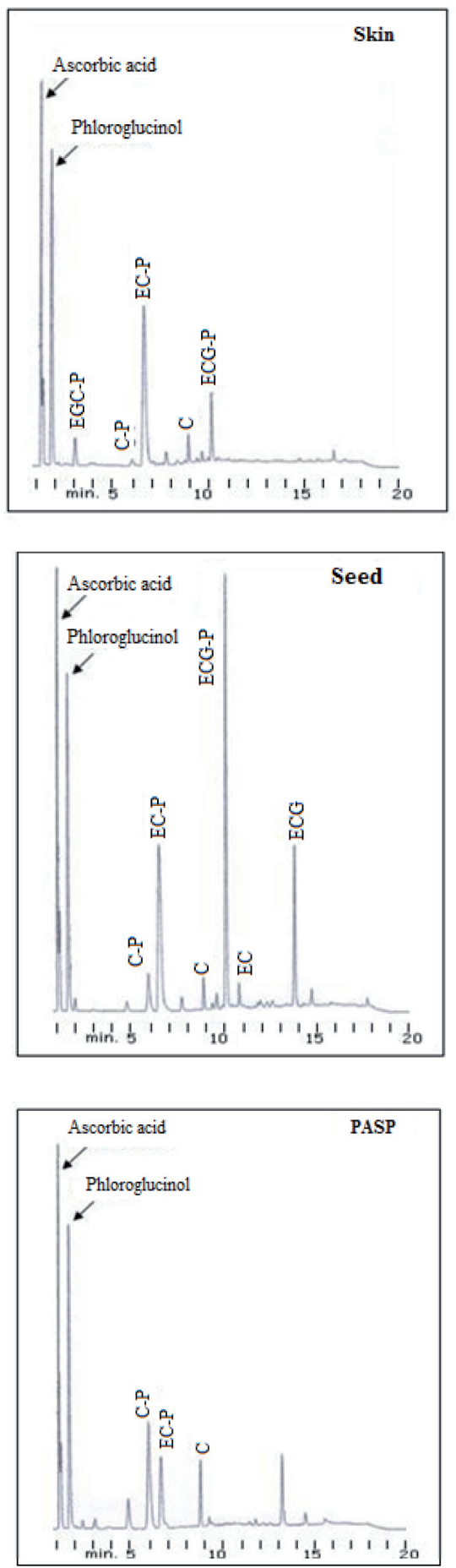

Figure 3. HPLC chromatograms to $280 \mathrm{~nm}$ from seed and skin grapes, and bark extracts without purification (PASP).The abbreviations represents the flavan-3-ols terminal subunits: $(+)$-catechin $(\mathrm{C}),(-)$-epicatechin (EC) and (-)-epicatechin-3-O-gallate (ECG); and extension subunits: $(+)$-catechin-phloroglucinol (C-P), (-)-epicatechinphloroglucinol (EC-P), (-)-epigallocatechin-phloroglucinol (EGC-P) and (-)-epicatechin-3-O-gallate-phloroglucinol (ECG-P).
Purification and fractioning of bark extract of Pinus radiata D. Don

As a result of the purification and fractioning of the PASP extract, four new extracts were generated (Figure 4). The same constitutive units (C-F, EC-F and C) of the PASP extract were identified in the chromatograms of the fractions FI, FII, FIII and FIV, but in a higher concentration, as observed by higher peaks (samples compared under identical conditions). However, the presence of the two unidentified peaks detected previously in PASP was only maintained in the fraction FI, while the rest of the fractions were lacking these unknown compounds. The remaining samples had the same flavonoid subunits; nevertheless, they presented different structural characteristics, which are discussed below.

Identification of bark proanthocyanidins from Pinus radiata D. Don

Table 2 summarizes the information on the mDP, mMW, concentration and R of PASP and the fractions FI, FII, FIII and FIV. The fractions FII, FIII, FIV did not present differences statistically significant in $\mathrm{R}$, unlike the fraction FI, which had the lowest concentration of flavonoid constitutive subunits. On the other hand, all the fractions including the PASP presented differences statistically significant in their mDP. The mDP of the fractions FI, FII, FIII and FIV increased according to the order how they were eluted, with the compounds with lower $\mathrm{mDP}$ in FI and the compounds of higher $\mathrm{mDP}$ in FIV, which is coincident with the results reported by Jerez et al. (2007a) for Pinus radiata.

The massic distribution of the fractions obtained from the purification of $3 \mathrm{~g}$ of PASP was between 0.2 and $0.92 \mathrm{~g}$, recovering $64 \%$ of the mass injected to the column. The fractions also presented physical differences mainly in color (visually), which might indicate that they are different samples. 


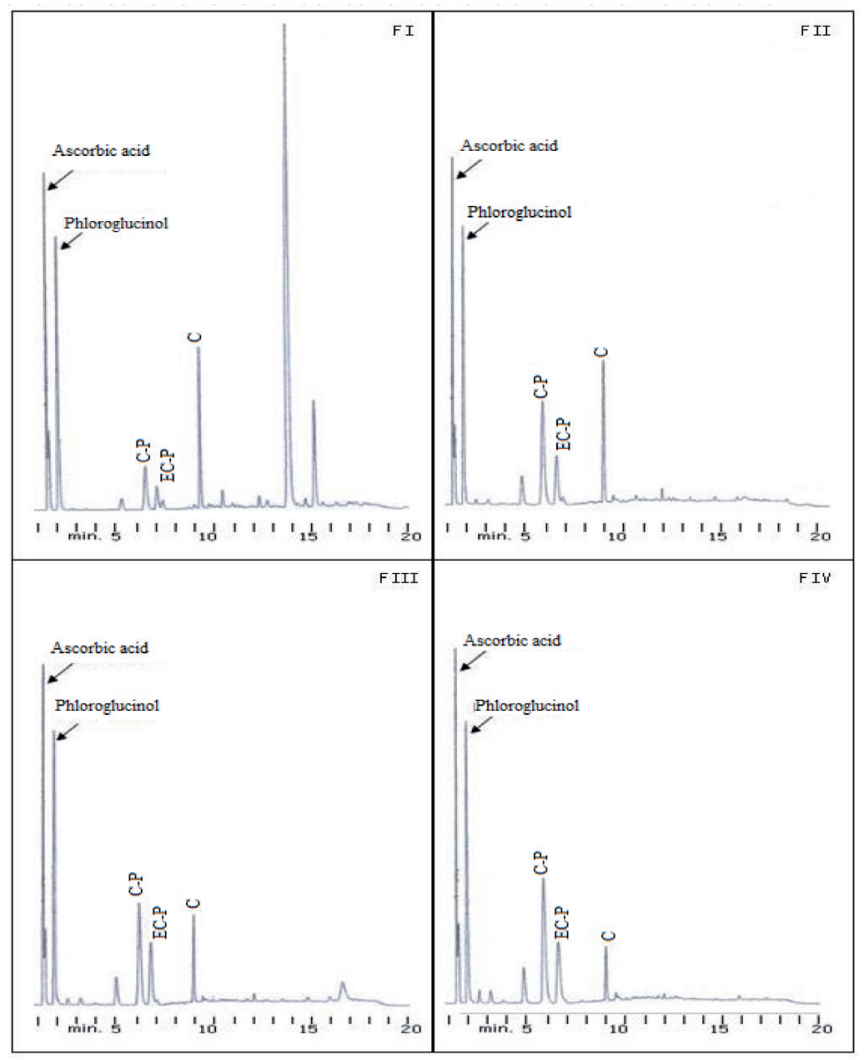

Figure 4. HPLC chromatograms from the fractions FI, FII, FIII y FIV to $280 \mathrm{~nm}$, showing terminal subunit, $(+)$-catechin (C) and extension subunits, (+)-catechin-phloroglucinol (C-P), (-)-epicatechin-phloroglucinol (EC-P).

Table 2. Structural characteristics of the fractions from Pinus radiata D. Don.

\begin{tabular}{llccc}
\hline Fraction & $\mathrm{R}(\% \mathrm{w} / \mathrm{w})$ & $\mathrm{mDP}$ & $\mathrm{mMW}$ & $\begin{array}{c}\text { Concentration } \\
(\mathrm{mg} \cdot \mathrm{mL}-1)\end{array}$ \\
\hline FI & $24.3 \pm 1.5 \mathrm{a}$ & $2.0 \pm 0.1 \mathrm{a}$ & $566 \pm 29 \mathrm{a}$ & $243 \pm 15 \mathrm{a}$ \\
FII & $36.1 \pm 1.3 \mathrm{c}$ & $3.6 \pm 0.2 \mathrm{~b}$ & $1033 \pm 58 \mathrm{~b}$ & $361 \pm 13 \mathrm{c}$ \\
FIII & $35.5 \pm 1.0 \mathrm{bc}$ & $5.3 \pm 0.1 \mathrm{c}$ & $1526 \pm 37 \mathrm{c}$ & $355 \pm 10 \mathrm{bc}$ \\
FIV & $36.8 \pm 2.0 \mathrm{c}$ & $9.3 \pm 0.3 \mathrm{e}$ & $2693 \pm 82 \mathrm{e}$ & $368 \pm 20 \mathrm{c}$ \\
PASP & $33.2 \pm 0.7 \mathrm{~b}$ & $6.0 \pm 0.2 \mathrm{~d}$ & $1735 \pm 47 \mathrm{~d}$ & $332 \pm 7 \mathrm{~b}$ \\
\hline
\end{tabular}

Values are express as mean value $\pm \operatorname{SD}(n=3)$.

Different letters indicate significant differences in the column $(\mathrm{p}<0.05)$ and the use of the same letter indicates that significant differences do not exist, therefore they belong to the same homogeneous group.

The content of total phenols, tannins concentration, and antioxidant activity of the extracts are presented in Table 3. The phenols concentration decreased according to the order how the fractions FI, FII, FIII and FIV were eluted. The antioxidant activity (expressed as inhibition percentage of peroxidation of linoleic acid) did not pres- ent differences between the purified samples and the PASP sample. On the other hand, the DPPH analysis made to two concentrations of different extract ( 6 and $12 \mu \mathrm{g} \cdot \mathrm{mL}^{-1}$ ), showed an increase of the antioxidant activity up to $3.6 \mathrm{mDP}$, and then a decrease as the mDP increased. Jerez et al. (2007a), with the same analysis, obtained a 
higher antioxidant activity in the fraction with mDP equal to 7 (for the case of Pinus pinaster) and in the fraction with $\mathrm{mDP}$ equal to 6.5 (for the case of Pinus radiata D. Don).

The increase of the antioxidant activity with $\mathrm{mDP}$ up to 3.6 may be explained by the electron delocalization through the intramolecular bonds between monomers, because the link $\mathrm{C}_{4}$ $\mathrm{C}_{8}$ of the flavan -3-ols provides a tight conformation, but in a specific point, new units in the PAs structure may represent a decisive esteric obstacle in the interaction with the substrate (Gaulejac et al., 1999). Therefore, Gaulejac et al. (1999) found an increase of the activity for PAs of 1 to 4 units and Jerez et al. (2007a) found an increase up to 6-7 units, and then, a stabilization (Pinus pinaster 12-22 mDP) or a fall (Pinus radiata $9-15 \mathrm{mDP}$ ) of the antioxidant activity. On the other hand, Ku and Mun (2008) analyzed different PAs fractions with MALDI-TOF MS, obtained from the fractioning of the phenolic extract of Pinus radiata D. Don bark. They showed different $\mathrm{mDP}$ and a powerful antioxidant activity that was significantly dependent of the content and the PAs characteristics, where the highest antioxidant activity was obtained for the oligomeric PAs, which contained from dimers to hexamers.

When the antioxidant activity was related to the tannins concentration and the mDP, it was observed that, with an increased mDP, the tannins concentration and the antioxidant capacity increased up to $\mathrm{mDP}$ equal to 3.6, and then it decreased, a tendency coinciding to the reports by Jerez et al. (2007a). Finally, it may be deduced from the previous relations that the antioxidant activity increased with the increment of the tannins concentration and that the maximum level corresponds to the fraction FII.

The antioxidant activity, evaluated as the scavenging capacity of the radical DPPH, showed a high antiradical activity in all the fractions analyzed in this study and, in addition, that activity was proportional as the concentration of the samples analyzed increased from 6 to 12 $\mu \mathrm{g} \cdot \mathrm{mL}-1$. In addition, the fractions FI, FII, FIII and FIV presented values of antiradical activity higher than a known commercial antioxidant, BHT, except for the unpurified sample. This result clearly indicated that bark from Pinus radiata D. Don presents highly commercial antioxidant properties, and that the purification of the bark extracts was necessary to eliminate the components that might interfere in the activities of the samples analyzed, and that the structural characteristics may be correlated with the antioxidant activity of the extract.

\section{Acknowlegemnt}

The authors thank the D.I. UdeC No. 208.0960621.0 project Dirección de Investigación Universidad de Concepción, Concepción, Chile.

Table 3. Chemical characteristics of the fractions from Pinus radiata D. Don.

\begin{tabular}{|c|c|c|c|c|c|}
\hline \multirow[t]{2}{*}{ Sample } & \multirow{2}{*}{$\begin{array}{l}\text { Total Phenols } T_{P} \\
\left(\text { g eq.C } \cdot \text { g ext. }{ }^{-1} \text { ) }\right.\end{array}$} & \multirow{2}{*}{$\begin{array}{c}\text { Tannins } C_{t} \\
\text { (mg eq. } \mathrm{C} \mathrm{g} \mathrm{ext.-1} \text { ) }\end{array}$} & \multirow{2}{*}{$\begin{array}{c}\mathrm{IP}(\%), \text { FTC } \\
1 \mu \mathrm{g} \cdot \mathrm{mL}^{-1}\end{array}$} & \multicolumn{2}{|c|}{ CSRL (\%), DPPH } \\
\hline & & & & $\overline{6 \mu \mathrm{g} \cdot \mathrm{mL}^{-1}}$ & $12 \mu \mathrm{g} \cdot \mathrm{mL}^{-1}$ \\
\hline FI & $7.31 \pm 0.2 \mathrm{c}$ & $494 \pm 3 \mathrm{a}$ & $139 \pm 0.9 \mathrm{a}$ & $31.1 \pm 1.36 \mathrm{a}$ & $84.7 \pm 0.85 \mathrm{a}$ \\
\hline FII & $6.04 \pm 0.3 b$ & $773 \pm 15 c$ & $143 \pm 0.4 \mathrm{c}$ & $48.1 \pm 0.64 \mathrm{~b}$ & $81.8 \pm 0.00 \mathrm{a}$ \\
\hline FIII & $5.86 \pm 0.1 \mathrm{~b}$ & $705 \pm 12 b$ & $145 \pm 0.8 \mathrm{c}$ & $36.6 \pm 1.06 \mathrm{c}$ & $74.5 \pm 1.77 b$ \\
\hline FIV & $4.79 \pm 0.2 \mathrm{a}$ & $700 \pm 26 b$ & $142 \pm 0.6 \mathrm{bc}$ & $35.1 \pm 1.21 \mathrm{c}$ & $67.1 \pm 0.35 \mathrm{c}$ \\
\hline PASP & $4.96 \pm 0.2 \mathrm{a}$ & $511 \pm 12 \mathrm{a}$ & $143 \pm 1.7 b c$ & $27.8 \pm 1.00 \mathrm{~d}$ & $51.9 \pm 2.33 \mathrm{~d}$ \\
\hline BHT & - & - & - & $34.8 \pm 0.81 \mathrm{c}$ & $52.5 \pm 0.36 \mathrm{c}$ \\
\hline
\end{tabular}

Values are express as mean value \pm SD $(n=3)$.

Different letters indicate significant differences in the column $(p<0.05)$ and the use of the same letter indicates that significant differences do not exist, therefore they belong to the same homogeneous group. 


\title{
Resumen
}

\begin{abstract}
S. Cortés, H. Pulgar, V. Sanhueza, E. Aspé y K. Fernández. 2010. Identificación de las proantocianidinas extraídas desde corteza de Pinus Radiata D. Don. Cien. Inv. Agr. 37(2): 15-25. La corteza de Pinus radiata D. Don es reconocida como una fuente natural rica en proantocianidinas (PAs). Fue extraída la corteza de Pinus radiata D. Don, para originar un extracto sin purificar, y luego este extracto fue purificado, para producir 4 fracciones con el objeto de relacionar sus características estructurales con la capacidad antioxidante del extracto. La caracterización estructural se realizó por catálisis ácida en presencia de floroglucinol, seguido de la detección de los componentes por cromatografía líquida de alta presión (HPLC). Las subunidades identificadas en la corteza de Pinus radiata D. Don fueron: epicatequina-

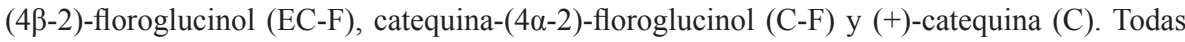
las fracciones analizadas mostraron distintos grados de polimerización medio ( $\mathrm{mDP}$ ), peso molecular medio (mMW), concentración y rendimiento $(\mathrm{R})$ de la reacción con floroglucinol. La concentración de fenoles totales disminuyó de acuerdo al orden en que fueron eluídas las fracciones. Todas las fracciones presentaron una alta actividad antiradical (evaluada como capacidad atrapadora del radical DPPH). Sin embargo, la fracción FII presentó la mayor concentración de taninos y la mayor actividad antioxidante. Las características estructurales del extracto de corteza de Pinus radiata D. Don pudieron ser correlacionadas con la actividad antioxidante del extracto.
\end{abstract}

Palabras clave: Capacidad antioxidante, corteza, Pinus radiata, taninos.

\section{References}

Balaban, M., and G. Ucar. 2001. Extractives and structural components in wood and bark of endemic oak Quercus vulcanica Boiss. Holzforschung 55: 478-486.

CORMA, 2007. Sector forestal Chileno/Recurso forestal. Available online at: http://www.corma. cl/corma info.asp?idq $=43$ (Website accessed: 22 June, 2010).

Cutler, G.J., J.A. Nettleton, J.A. Ross, L.J. Harnack, D.R. Jacobs, C.G. Scrafford, L.M. Barraj, P.J. Mink, and K. Robien. 2008. Dietary flavonoid intake and risk of cancer in postmenopausal women: The Iowa Women's Health Study. International Journal of Cancer 123: 664-671.

Diouf, P. N., A. Merlin, and D. Perrin 2006. Antioxidant propierties of wood extract and colour stability of Woods. Annals of Forest Science 63: 525-534.

Egaña, P., and C. Palma .1999. Catastro y evaluación de los recursos vegetacionales nativos de Chile. Protocolo de Acuerdo CONAF-CONAMA. Universidad Austral de Chile, Pontificia Universidad Católica de Chile y Universidad Católica de Temuco, Chile.
Gaulejac, N., N. Vivas, V. Freitas, and G. Bourgeois. 1999. The influence of various phenolic compounds on scavenging activity assessed by an enzymatic method. Journal of the Science of Food and Agriculture 79: 1081-1090.

Hagerman, A. E. 2002. Tannin Handbook. Available online at: http://www.users.muohio.edu/hagermae/tannin.pdf (Website accessed: 13 March, 2009).

Jerez, M., M. Pinelo, J. Sineiro, and M.J. Nunez. 2006. Influence of extraction conditions on phenolic yields from pine bark: assessment of procyanidins polymerization degree by thiolysis. Food Chemistry 94: 406-414.

Jerez, M., S. Tourino, J. Sineiro, J.L. Torres, and M.J. Nunez. 2007a. Procyanidins from pine bark: Relationships between structure, composition and antiradical activity. Food Chemistry 104: 518527.

Jerez, M., A. Selga, J. Sineiro, J.L. Torres, and M.J. Nunez. 2007b. A comparison between bark extracts from Pinus pinaster and Pinus radiata: Antioxidant activity and procyanidin composition. Food Chemistry 100: 439-444.

Kennedy, J.A., and G.P. Jones. 2001. Analysis of proanthocyanidin cleavage products following acidcatalysis in the presence of excess phloroglucin- 
ol. Journal of Agricultural and Food Chemistry 49: 1740-1746.

Kennedy, J.A., and A.W. Taylor. 2003. Analysis of proanthocyanidins by high-performance gel permeation chromatography. Journal of Chromatography A 995: 99-107.

Kim, Y.M., M.H. Wang, and H.I. Rhee. 2004. A novel alpha-glucosidase inhibitor from pine bark. Carbohydrate Research 339: 715-717.

Koleckar, V., K. Kubikova, Z. Rehakova, K. Kuca, D. Jun, L. Jahodar, and L. Opletal. 2008. Condensed and hydrolysable tannins as antioxidants influencing the health. Mini-Reviews in Medicinal Chemistry 8: 436-447.

Ku, C.S., and S.P. Mun. 2007. Characterization of proanthocyanidin in hot water extract isolated from Pinus radiata bark. Wood Science and Technology 41: 235-247.

$\mathrm{Ku}$, C.S., and S.P. Mun. 2008. Antioxidant properties of monomeric, oligomeric, and polymeric fractions in hot water extract from Pinus radiata bark. Wood Science and Technology 42: 47-60.

Maldonado, J. 2008. Obtención de una antioxidante natural a partir de Pinus radiata D. Don. Memoria de Título, Departamento de Ingeniería Química, Universidad de Concepción, Chile.

Mihara, R., K.M. Barry, C.L. Mohammed, and T. Mitsunaga. 2005. Comparison of antifungal and antioxidant activities of Acacia mangium and A-auriculiformis heartwood extracts. Journal of Chemical Ecology 31: 789-804.

Nishioka, K., T. Hidaka, S. Nakamura, T. Umemura, D. Jitsuiki, J. Soga, C. Goto, K. Chayama, M. Yoshizumi, and Y. Higashi. 2007. Pycnogenol (R), French maritime pine bark extract, augments endothelium-dependent vasodilation in humans. Hypertension Research 30: 775-780.
Palma, G., J. Ferrer, and J. Baeza. 2003. Removal of metal ions by modified Pinus radiata bark and tannins from water solutions. Water Research 37 : 4974-4980.

Rosales, M., and R. F. González. 2003. Comparación del contenido de compuestos fenólicos en la corteza de ocho especies de pino. Madera y Bosques 9: 41-49.

Sarneckis, C.J., R.G. Dambergs, P. Jones, M. Mercurio, M.J. Herderich, and P.A. Smith. 2006. Quantification of condensed tannins by precipitation with methyl cellulose: Development and validation of an optimised tool for grape and wine analysis. Australian Journal of Grape and Wine Research 12:39-49.

Schofield, P., D. M. Mbugua, and A. N. Pell. 2001. Analysis of condensed tannins: a review. Animal Feed Science and Technology 91: 21-40.

Tourio, S., A. Selga, A. Jimenez, L. Julia, C. Lozano, D.L. Lizarraga, M. Cascante, and J.L. Torres. 2005. Procyanidin fractions from pine (Pinus pinaster) bark: Radical scavenging power in solution, antioxidant activity in emulsion, and antiproliferative effect in melanoma cells. Journal of Agricultural and Food Chemistry 53: 4728-4735.

Weber, H.A., A.E. Hodges, J.R. Guthrie, B.M. O'Brien, D. Robaugh, A.P. Clark, R.K. Harris, J.W. Algaier, and C.S. Smith. 2007. Comparison of proanthocyanidins in commercial antioxidants: Grape seed and pine bark extracts. Journal of Agricultural and Food Chemistry 55: 148-156.

Yassa, N., H.R. Beni, and A. Hadjiakhoondi. 2008. Free Radical Scavenging and Lipid Peroxidation Activity of the Shahani Black Grape. Pakistan Journal of Biological Sciences 11: 805-809. 
